\title{
EFFECTS OF REST AND NO-REST PERIODS UPON GROWTH OF SOLANUM
}

\author{
W. F. GERICKE
}

That important chemical and physiological changes occur in plants, seeds, and bulbs during their rest period has been shown by several investigations. These investigations have been carried out with a considerable number of plants, seeds, and bulbs. Those studies which concerned themselves with the changes in the composition of the potato have been found of especial interest to the present study because of the light they have thrown upon the importance of the chemical changes in the composition of the tubers on the later physiological activities of the plant.

Briefly touching on some of the literature of rest period studies in which the chemical aspect of the problem was considered, we find that the subject matter resolves itself into three general phases: (a) the influence on the permeability of the integument, (b) the influence on the chemical changes in the embryo, $(c)$ the influence on the reserve food material.

Crocker (2) has explained some of the causes of delayed germination as being due to the resistance of the integument of the seed to water and oxygen. His experiments with Xanthium showed very clearly that the long dormant period of one of the embryos was simply a question of the imperviousness of the seed coat. Thus in this case the problem of the so-called rest period resolved itself into the adoption of a method to overcome the resistance of the seed coat and to allow water and oxygen to penetrate the tissues.

ECKERSON (3) found that after-ripening processes also involved chemical changes in the embryo. The water-holding capacity and the reaction of the embryonic tissue of Crataegus, the species used for the experiment, were found to change during the rest period. Cotyledons and hypocotyls gave different kinds of reactions during the after-ripening processes, due to the results of enzymatic activities. 
As early as I890 JoHANnsen (5) studied the effects on afterripening of ether treatment. His work with the chemical changes in the after-ripening of bulbs led him to conclude that the lack of growth or the slow growth of the plant during the so-called rest period was not due to the lack of soluble food. His ether treatment of bulbs decreased the length of the after-ripening period, but he was unable to report any important chemical changes due to the treatment, save that amide nitrogen seemed to have been increased in amount.

Müller-Thurgau and Schnemer-Orelli (7) conducted an extensive investigation on the chemical and enzymatic changes in potatoes during the storage period. They found that the intensity of respiration was increased by a certain rise in temperature. Respiration likewise was increased with the relative age of the tubers. The increased respiration varied with the sugar content, and active enzymes were present at all stages of the rest period. A certain equilibrium between starch and sugar formation was observed.

APPleman (I) found diastatic activity greater in cold storage potatoes than in those stored at room temperature. After-ripening was found to affect the buds rather than the tubers. The chemical changes of after-ripening concerned carbohydrates chiefly. Proteins, lipoids, organic extractives, and inorganic phosphorus remained constant up to the time of sprouting, and no changes were discernible in the proteolysis of the various nitrogen compounds. Metabolic changes of the proteins began rather suddenly, and were found to be concurrent with sprouting, but were not considered the primary processes of after-ripening.

HOWARD's (4) work on factors concerned with the rest period is of great interest, both as to the extent of his investigations and as to the bibliography of the subject. His experiments show, as KLEBS (6) had already indicated, that the rest period is not a fixed or unchangeable character of plants, but is instead a condition brought about by internal and external agencies. Both HowARD and KLEBS concluded that although the morphology of a plant is linked up within the protoplasm and the specific structure of the cells, external conditions are of great importance in determining certain outward forms of plant responses. 
In the light of the investigations above mentioned the present experiment was undertaken to ascertain whether any vegetative changes in form would develop in the plants grown from tubers of different rest period duration, and to what extent correlation, if any, could be drawn from changes in the chemical composition of the tubers during the rest period. The experiment was carried out in the greenhouse. Due precautions were observed in order to attain uniform and comparable conditions of moisture, temperature, and culture throughout the length of the experiment. Plantings were made at different seasons of the year to eliminate as much as possible the influence of the variation of climate. The potatoes were planted and grown to maturity in large earthen pots containing I 2 K. of a good loam soil. New soil was used for every planting and the tubers were planted to a depth of 3 inches unless otherwise indicated. The harvest of the crop at maturity was at the time when the leaves began to dry and fall, while the water content of the soil was still at optimum condition. As the tables indicate, tubers of various rest period durations were used. Plants were grown from tubers of a continuous no-rest period treatment of several generations, as well as from those of rest period treatment also of several generations. The results obtained are indicated in the tables.

A potato known as the Salinas Burbank was used as the original seed for the experiment. It was cut into two nearly equal parts of $\mathrm{I}_{5} \mathrm{O} \mathrm{gm}$. weight, and planted. Periods of Io and I I days respectively were required for the plants to appear from these two half tubers. Three stalks were produced from one half tuber and four stalks from the other. Rapid growth and strong stalk production characterized these plants. Maturation occurred for the duplicate plants in 86 and 90 days respectively from the time of planting, while the actual growing period from the day of appearance of the plants above ground to the harvest averaged $77 \cdot 5$ days.

Series II were the plants produced from seed taken from the crop of series I and were planted immediately after harvest. In this series the potatoes planted were whole tubers of approximately roo gm. each. Periods of 62 and 67 days were required for the seedlings to appear in the duplicate pots. In this series one-stalked 


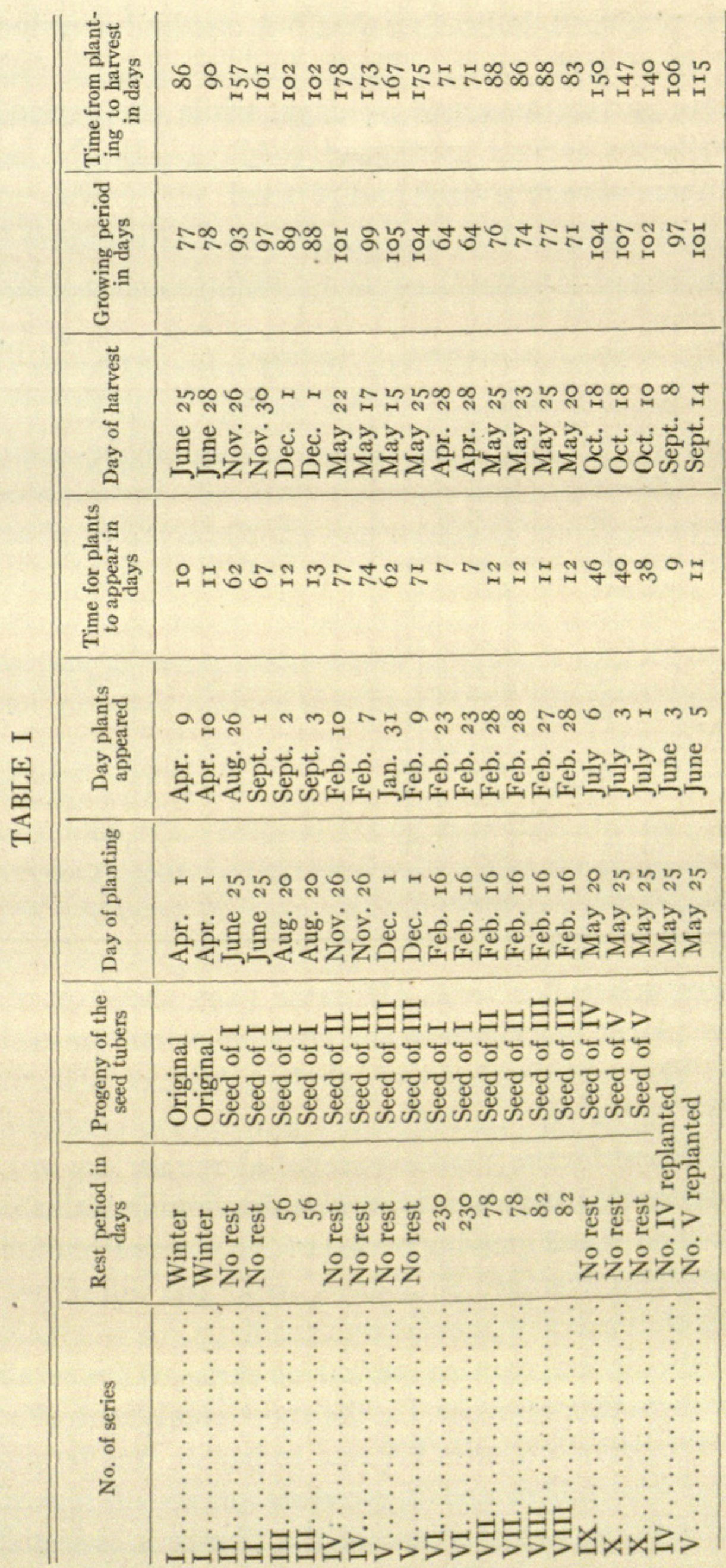


plants were produced, indicating that but one bud germinated and developed from each tuber. The actual growing period of the plants above surface averaged 95 days, while the period of time from planting to harvest averaged I $_{59}$ days. In this series the old seed tubers were recovered and planted.

TABLE II

\begin{tabular}{|c|c|c|c|c|c|}
\hline No. of series & $\begin{array}{l}\text { Rest period in } \\
\text { days }\end{array}$ & $\begin{array}{l}\text { Progeny of the } \\
\text { seed tubers }\end{array}$ & $\begin{array}{l}\text { No. of stalks } \\
\text { per plant }\end{array}$ & $\begin{array}{l}\text { Weight of crop } \\
\text { in gm. }\end{array}$ & $\begin{array}{l}\text { No. of potatoes } \\
\text { produced per } \\
\text { plant }\end{array}$ \\
\hline 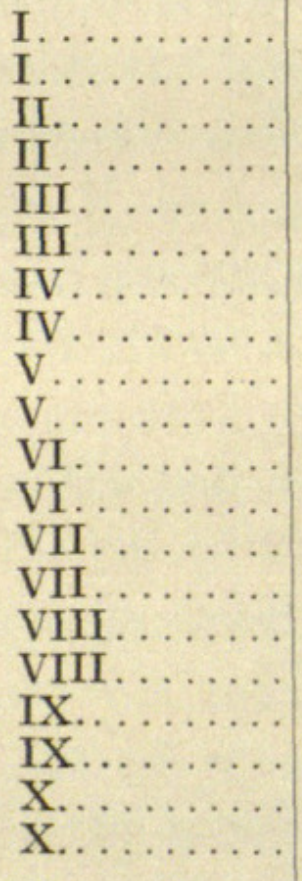 & $\begin{array}{r}\text { Winter } \\
\text { Winter } \\
\text { No rest } \\
\text { No rest } \\
56 \\
56 \\
\text { No rest } \\
\text { No rest } \\
\text { No rest } \\
\text { No rest } \\
230 \\
230 \\
78 \\
78 \\
82 \\
82 \\
\text { No rest } \\
\text { No rest } \\
\text { No rest } \\
\text { No rest }\end{array}$ & $\begin{array}{l}\text { Original } \\
\text { Original } \\
\text { Seed of I } \\
\text { Seed of I } \\
\text { Seed of I } \\
\text { Seed of I } \\
\text { Seed of II } \\
\text { Seed of II } \\
\text { Seed of III } \\
\text { Seed of III } \\
\text { Seed of I } \\
\text { Seed of I } \\
\text { Seed of II } \\
\text { Seed of II } \\
\text { Seed of III } \\
\text { Seed of III } \\
\text { Seed of IV } \\
\text { Seed of IV } \\
\text { Seed of V } \\
\text { Seed of V }\end{array}$ & $\begin{array}{l}3 \\
4 \\
\mathrm{I} \\
\mathrm{I} \\
3 \\
3 \\
\mathrm{I} \\
\mathrm{I} \\
\mathrm{I} \\
\mathrm{I} \\
5 \\
6 \\
3 \\
4 \\
4 \\
3 \\
3 \\
\mathrm{I} \\
\mathrm{I} \\
\mathrm{I} \\
\mathrm{I}\end{array}$ & \begin{tabular}{|c|}
491.0 \\
$513 \cdot 2$ \\
230.8 \\
208.0 \\
300.0 \\
263.0 \\
437.0 \\
409.1 \\
303.3 \\
280.5 \\
47.4 \\
50.2 \\
356.0 \\
263.0 \\
Did not harve \\
Did not harve \\
205.2 \\
287.3 \\
295.1 \\
344.2
\end{tabular} & $\begin{array}{r}\text { II } \\
\text { I3 } \\
6 \\
3 \\
8 \\
7 \\
7 \\
\text { I } \\
3 \\
2 \\
\text { II } \\
\text { I4 } \\
6 \\
7\end{array}$ \\
\hline
\end{tabular}

The seed tubers for series III came from the crop of series I which were placed in a closet in the greenhouse and protected from sunlight. The seed consisted of whole tubers of about $100 \mathrm{gm}$. weight and had a rest period under greenhouse conditions of $5^{6}$ days. In this series the plants appeared above surface in $\mathrm{I} 2$ and $\mathrm{I} 3$ days respectively, 3 buds sprouting and developing stalks in each of the pots. The actual growing period of the plants from the appearance of seedlings averaged 88.5 days, while the time from the day of planting to the day of harvest was 102 days.

While the actual growing period of series III was about one week less than that of series II, the most significant effect of the 56 days' rest period of series III was to hasten the germination of the buds of the tubers and to produce plants of several stalks, instead of one, as was the case of the plants in series II. The 
after-ripening processes of the potatoes, therefore, proceeded in the soil, but the degree and perhaps the specificity of the processes were different from those occurring in the tubers under ordinary conditions of storage. That the $5^{6}$ days of rest period did not materially shorten the total time required for the seed potatoes harvested from series I to produce a crop is evident from the fact that the total time required for series II and III to produce a crop from the harvest of the tubers from which they grew, namely, series $\mathrm{I}$, is about the same as indicated in the sum of the rest period and growth period of the two series. The germination of one bud in the tubers of the no-rest period may indicate the localization of the products of the after-ripening processes. The failure of other buds to sprout while the one stalk was growing and maturing a crop could have been due in part to the insufficiency of proper plant food in the tuber. Furthermore, the production of substances by the growing plant which could act inhibitively to the germination of other buds of the tubers may offer a partial explanation for the failure of other stalks to make their appearance. The fact that the seed tubers of the no-rest series remained in the ground for a long time without decay may indicate the presence of some protective agent, or that the condition of the tuber was such as to preclude bacterial decomposition. The probable lack of both sugar formation and the hydrolysis of other food material in the no-rest period tubers may be causes that have not permitted the development of the organisms of decomposition.

In series IV, another no-rest period set, half tubers of 82 and $89 \mathrm{gm}$. weight respectively were used for planting. The time required for the plants to appear above ground was 77 and 74 days for the duplicate pots. The actual growing period of the visible plants averaged roo days, and the time from planting to harvest averaged I75 days. Similarly to series II, just onestalked plants were produced, indicating the germination and growth of one bud for each half tuber.

Series V, another no-rest period set, was planted with whole tubers of 53.6 and $56.9 \mathrm{gm}$. weight from the crop of series III. The results obtained for this series were similar in all respects to those obtained for series IV, as the results in table III show. The 
original seed tubers of series IV and V were recovered, the soil carefully removed, and the potatoes weighed. The results are given in table III.

Series VI was planted with tubers produced from series I. These potatoes were kept in a closet in the greenhouse away from sunlight, but otherwise subjected to practically the same conditions as prevailed in the greenhouse. The rest period of this seed was 230 days. The loss of weight of the potatoes during the rest period was not determined, but the loss was considerable as the

TABLE III

\begin{tabular}{l|c|c|c}
\hline \hline Series & $\begin{array}{c}\text { Original weight } \\
\text { in gm. }\end{array}$ & $\begin{array}{c}\text { Weight after } \\
\text { maturation of one } \\
\text { crop in gm. }\end{array}$ & $\begin{array}{c}\text { Loss of weight } \\
\text { in gm. }\end{array}$ \\
\hline IV $\ldots \ldots \ldots \ldots$ & 82 & 82 & 0.0 \\
IV $\ldots \ldots \ldots \ldots$ & 89 & 88.7 & 0.3 \\
V $\ldots \ldots \ldots \ldots$ & 53.6 & 53 & 0.6 \\
V......... & 56.9 & Not recovered & \\
\hline
\end{tabular}

tubers were badly shriveled. The appearance of the seedlings above surface in the form of several stalks occurred on the seventh day after planting. The actual growing period was 64 days, and the period from planting to harvest $7 \mathrm{I}$ days. While series VI went through the growth cycle in less time than any other series, the actual production, both as to size of the plants and weight of tubers produced, was much less than that of any other crop of the entire experiment.

Series VII and VIII were planted with tubers from the crops produced from series II and III respectively. The rest period for the seed of the former was 78 days and for the latter 82 days. The plants appeared in 12 days, and the growing period above ground averaged 75 and 74 days respectively, while the time from the day of planting to the day of harvest averaged 87 and 85.5 days respectively. Several stalks per plant were produced in all cases. Series VII and VIII came the nearest of any in the entire experiment to simulating series I, which may be considered the normal series, because it was grown from tubers that had the normal rest period, coming from winter storage. 
Series IX and X represent the third and second generations of a continuous no-rest treatment series. The seed potatoes for these series were halved; one part was planted and the other half kept for analysis. The purpose was to compare the analysis of tubers which had produced a crop with that of normal potatoes and thus learn how much of the plant food in the tubers is used in the growth of a crop. The results obtained in series IX and X were similar to those already stated for other no-rest period series. One-stalked plants were produced in all cases. A period of 46 days was required for series IX to appear above ground, while the plants of series X appeared on an average of 39 days. The average length of the actual growing period above ground was ro4 days, which is about 4 weeks longer than that of series I, VII, and VIII, the normal ones for this variety of potato.

The seed tubers of series IV and V were recovered and planted as already mentioned. The appearance of the plants above ground from this second planting occurred in 9 and II days, which was much less time than that required for their appearance at the first planting. The actual growing period of the plants above surface was 97 and Ior days, a long period, similar in this respect to the case of their first planting. Three to four stalks developed from the tubers instead of one stalk, as was the case in the first crop of this series.

That the growth of some plants can be affected by rest period changes in the composition of its seeds or bulbs has been shown by this experiment with the potato. The most significant effect observed was the variation in the length of the growing period, both as to the length of time required for the plants to appear and the length of the actual growing period above ground. The potatoes planted immediately after harvest to the depth of 3 inches produced one-stalked plants. All of these forms of plant responses undoubtedly were influenced by certain chemical changes in the tuber indicated to some extent by the various investigations mentioned. That the after-ripening changes in the potatoes used in this experiment, because of the conditions imposed upon the seed tubers, may have been affected in the rate, quantity, and specificity of their reactions, seems a reasonable conclusion. 
The potato grown from the seed of the normal rest period treatment produced plants of several stalks. Judging from the investigations $(\mathbf{I}, 7)$ already referred to, one would expect that in these tubers the products of chemical reactions had approached a certain equilibrium, so that the sugar formation was at its maximum, and conditions were optimum for the activity of the diastatic enzymes. The potatoes planted without rest period treatment could not undergo similar changes as those of the normal rest period ones, as the agency of vegetative growth induced by the peculiar condition under which the tubers were placed would preclude the attainment of a similar chemical equilibrium as that existing in the tubers of the normal resting period treatment.

That not all of the food material in the seed tubers was used in the growth of the plants was shown by the fact that the seed potato, when planted again, germinated, grew, and matured a crop. In the second growth of the tuber several stalk plants appeared above ground in about the normal time. Excepting the fact that the second planting was not carried out with a sufficient number of plants for conclusive results, the results obtained indicated that the after-ripening of the potato, while it grew a crop, did not serve to decrease materially the growing period of the plant for its second growth.

With a more detailed study of the potato by means of the analyses of the seed tubers before and after their plant production, some data may be obtained which may throw light upon this interesting phase of plant physiology.

\section{Summary}

I. A study of the effect of various rest periods of the potato tuber upon the subsequent growth of the plants is here reported.

2. After-ripening processes in the potato occurred whether the tubers were in the ground or in ordinary storage.

3. Potatoes planted immediately after the maturation of a crop required a much longer period for the germination of the buds and the appearance of the plants above ground than did potatoes that had a rest period. 
4. The no-rest period tubers, when planted, produced onestalked plants, indicating the germination and growth of one bud.

5. Plants grown from the no-rest period tubers had a longer growing period than did plants grown from the normal rest period tubers.

6. Most of the seed tubers of the no-rest series plants were recovered. These potatoes had lost very little in weight. When these tubers were planted the second time, germination and growth of several buds ensued. The plants appeared above ground in about the same time period required for the plants of the normal rest period tubers. The growing period of the no-rest period plants in the second planting was nearly equal to that of their first planting.

University of CALIFornia

\section{LITERATURE CITED}

I. Appleman, C. O., Study of rest period in potato tubers. Md. Exp. Sta. Bull. I83. I9I4.

2. Crocker, W., Rôle of seed coats in delayed germination. Bot. Gaz. 42: 265-29I. I 906 .

3. Eckerson, S. H., A physiological and chemical study of after-ripening. Bот. GAZ. $55: 286-299$. I9I3.

4. Howard, W. L., An experimental study of the rest period in plants. Mo. Exp. Sta. Res. Bull. I. I9ro.

5. Johannsen, W., Das Ätherverfahren beim Frühtreiben. 2 Auflage Jena. I906.

6. Klebs, Georg, Entwickelungsänderungen bei Pflanzen. Jena. I903.

7. Müller-Thurgau, H., and Schneider-Orelli, O., Kenntnis der Lebenvorgange in ruhenden Pflanzenteile. Flora ror:309-372. I910. 


\section{$2 \mathrm{BHL}$ Biodiversity Heritage Library}

Gericke, W. F. 1918. "Effects of Rest and No-Rest Periods Upon Growth of Solanum." Botanical gazette 65(4), 344-353. https://doi.org/10.1086/332248.

View This Item Online: https://www.biodiversitylibrary.org/item/109339

DOI: https://doi.org/10.1086/332248

Permalink: https://www.biodiversitylibrary.org/partpdf/224001

\section{Holding Institution}

Missouri Botanical Garden, Peter H. Raven Library

\section{Sponsored by}

Missouri Botanical Garden

\section{Copyright \& Reuse}

Copyright Status: Public domain. The BHL considers that this work is no longer under copyright protection.

This document was created from content at the Biodiversity Heritage Library, the world's largest open access digital library for biodiversity literature and archives. Visit BHL at https://www.biodiversitylibrary.org. 